\title{
Modernization and Popular Culture: Views from Turkey
}

\author{
Ozlem Aydogmus Ordem
}

Department of Communication, Çukurova University, Adana, Turkey

Copyright $\mathrm{O} 2018$ by authors, all rights reserved. Authors agree that this article remains permanently open access under the terms of the Creative Commons Attribution License 4.0 International License

\begin{abstract}
Studies on modernization and popular culture have been on the rise in recent decades since modernization has brought about popular culture and its elements. This study aims to focus on the relationship between modernization-popular culture and nine elements composed of critical theory, consumer culture, gender, cinema, media, high/low culture, power, art and image. The study involved 49 undergraduates at a Turkish university majoring in Communication Sciences. In addition, some participants $(\mathrm{N}=10)$ were interviewed regarding the relationship between modernization-popular culture and nine elements. An inductive content analysis was conducted to obtain the results. The study took 14 weeks and contained two questions to search for the relationship between modernization-popular culture and nine elements. The results show that the strongest relationships were composed of the elements of media, cinema and consumer culture, while the weakest relationships were between power, gender and popular culture.
\end{abstract}

Keywords Popular Culture, Modernization, Culture, Development

\section{Introduction}

The process of modernization goes back to Enlightenment era in the hope that progress would enable people to have control over nature [19]. A strong link between technological and economic progress was established. Industrialization and urbanization accelerated this progress, which also produced certain concerns. Inglehart and Welzel [19] maintain that the first theories regarding modernization came from Adam Smith and Karl Marx and that capitalism and communism were two important theories that vied with each other until 1950s. These two mainstream ideas involved people in modernization discussions. Modernization is often associated with economic, technological and social [17]. In addition to these areas of modernization, the area of industrial society is also often seen as the pivotal variable that shapes values of modernization that cause certain cultures to move away from their traditional values which are considerably criticized [28]. However, socioeconomic development in modernization plays a critical role [4] because elements of socioeconomic development contain predictable educational, political, economic and cultural changes [19]. Since socioeconomic development has an effect on survival of people who live in poor situations, it remains vital for them to accommodate changes taking place in socioeconomic area $[22,27]$. Thus, value changes become existential and necessary for them. Thus, modernization process produces diversity and flexibility in social ties and social roles that need to be accommodated by those who question their socioeconomic situation. Unlike fixed roles and dependency, individual and social autonomy are required [19]. Social limitations resulting from the nature of traditional societies and values that often remain fixed and stable lead people to gain social autonomy. Thus, modernization becomes a social tool to help them be emancipated from these constraints. Besides the areas mentioned above, the relationship between modernization and postindustrialization is also important to discuss.

The modernization in industrialization process is more associated with secularization of authority, whereas modernization in postindustrialization is closely linked to gaining autonomy and emancipation from authorities [19]. The latter modernization focuses on self-expression and individual rights that will free them from authorities. Thus, individual autonomy, development of direct democracy and self-expression values constitute the main elements of postindustrial modernization that produces dramatic cultural changes that do not proceed in a linear way. Mere socioeconomic development may be insufficient to create radical cultural changes and new value systems; unless direct democracy is developed and individual autonomy is provided [11, 14, and 23]. Therefore, modernization should 
always be perceived as multi-faceted and multi-layered [21, 31]. Although rapid changes in different societies exist, their cultural differences are preserved because belief systems are resistant and durable. Thus, modernization is perceived and interpreted in different ways in different societies [19, 21, 31]. Although the people in Ottoman Empire, for example, accepted the importance of modernization, the pioneers of modernization in Ottoman were criticized since it was believed that modernization of the West caused decadence and moral problems in the society $[13,26]$. Therefore, Western modernization is often fragmented in different cultures and cannot be understood in a reductionist way. In contrast, it is a subtle and complex process ranging from urbanization to political participation through direct democracy [21]. It is also a systemic process that refers to consistency. Although Inglehart and Welzel [18] emphasize that postindustrial modernization emphasizes the importance of individual autonomy and self-expression, these values sometimes remain ideal because this kind of modernization encounters some problems. One of the thorny issues is popular culture that creates cleavage between high and low cultures. Whose postindustrial modernization this is can be questioned because a dichotomy is created. Popular culture in postindustrial modernization is an enigma created by the ruling class and globalization $[19,18]$. Thus, it becomes crucial and critical to comprehend what popular culture is.

Popular culture is thought to have emerged after industrialization and urbanization [29, 32]. Williams [33] stresses the fact that popular culture is favored by many people and is perceived as inferior because any entity in popular culture becomes favored by many people. Storey [29] maintains that popular culture forms opposition to high culture and can be described as inferior culture. Similar to Storey [29] and Williams [33], Bourdieu [6] also portrays popular culture as a social element that aims to create masses with a commercial purpose. High culture is often defined as an individual practice and inclination for artistic purposes. Thus, it can be said that popular culture may not breed aesthetic feelings and be low in value. In addition, popular culture aims to address masses because the nature of popular entities is mass produced and mass consumption, which creates passive consumers who adhere to only consumption. Therefore, popular culture produces already-prepared and prefabricated products that aim to gather people around certain entities. All marketing strategies center on the mass and the people $[12,29]$. Various scientific studies are conducted to attract the masses that feel ready to consume products that are prepared for them. These strategies are also related to power, ideology, hegemony and capitalism because all these dominant institutions intend to create popular culture for those who have little or no power in these institutions. These people are called as masses, folks or working class $[5,24,29]$. Another aspect of popular culture is that it is political since the people in popular culture refer to any one in a certain society because dominant groups or in other words the ruling class try to impose certain ideas and entities on subordinate groups. Gramsci [15] calls this process hegemony. These people under the effect of popular culture are affected by hegemonic practices. Therefore, a conflict always occurs between these groups. Another movement that criticizes is Frankfurt School pioneers that name these practices and processes as culture industry [3]. Adorno and Horkheimer [1] define culture industry as a practice that creates homogeneity in societies. In line with Gramsci's term hegemony, they emphasize that popular culture helps authorities and dominant ideologies continue in the way they want because the people are always manipulated and controlled by immersive and imposing techniques. In addition, the people in popular culture are depoliticized and tend to lose their critical thinking skills. Marcuse [25] calls these people immersed in popular culture or in other words culture industry as one dimensional man because this popular culture prevents their critical thinking skills towards political issues. Hall [16], similarly, emphasizes that the people are deliberately and politically constituted in order for them to be manipulated and even depoliticized. Besides these aspects of popular culture, it is also related to postmodernism that deconstructs dichotomies between high and popular culture.

In line with the theories of modernization and popular culture discussed above, this study aims to unearth the link between modernization and popular culture by giving the participants nine elements studied in the classroom setting. The title of the class was modernization and popular culture. The participants were taught the theories of modernization and popular culture under nine elements composed of critical theory, consumer culture, gender, cinema, media, high/low culture, power, art and image. The elements were extracted from various mainstream books. The study intended to find out how the participants figured out the relationship between modernization-popular culture and the nine elements.

\subsection{Research Questions}

1. What are Turkish undergraduates' views regarding modernization and popular culture?

2. What are Turkish undergraduates' views regarding the relationship between popular culture and its elements?

\section{Method}

\subsection{Research Design}

The study was descriptive and qualitative in nature. The study included two research tools composed of semi-structured interviews and the participants' regarding 
about the relationship between modernization-popular culture and the nine elements There are two main approaches, inductive and deductive, to examine data in social sciences. The inductive approach aims to analyze specific data with possible categories whose definitions are hardly operationalized $[7,8,9,10]$. It is often composed of limited number of data that may not be replicated at cross-national level. In this study, an inductive content analysis was carried out to elicit the categories of the participants performed because inductive analysis entails extraction of topics, themes and categories from the data $[7$, $8,9,10,30]$. The participants were already given some elements pertinent to modernization and sub-categorization and told to determine the relationship between modernization-popular culture and the nine elements. In addition, the participants were interviewed to comment on modernization and popular culture.

\subsection{Participants}

The study involved 49 second year students majoring in Communication Sciences at a Turkish University. The participants did not receive any lesson regarding modernization and popular culture before. They studied modernization and popular culture for 48 hours in 14 weeks. The participants involved themselves in discussion activities in the classroom setting. In addition, 10 participants were interviewed about modernization and popular culture.

\subsection{Procedure}

The participants were taught elements of modernization and popular culture. These elements were composed of nine elements which were critical theory, consumer culture, gender, cinema, media, high/low culture, power, art and image. Each element was studied and taught to the participants for three hours. The study took 14 weeks, and each element was discussed with the participants. After the introduction of each element, the participants were asked two questions. The first question was about the strong and weak relationship between modernization/popular culture and the nine elements. The second question was about the interpretation of the relationship that they chose. They were asked to write at least 500 words about the relationship that they selected. In addition, 10 participants were interviewed regarding the relationship between modernization and popular culture.

\subsection{Data Analysis}

Data analysis was done by using basic descriptive statistics. The frequency of each element was calculated based on the weak and strong relationships. In addition, each element was interpreted within the framework of modernization and popular culture. Besides the analysis of the elements, an inductive analysis was performed by eliciting various categories.

\section{Findings}

This study aimed to scrutinize the relationship between modernization-popular culture and nine elements. The data elicited from the questions show that the participants tended to relate some elements more than to popular culture. Table 1 shows the relationships between popular culture and modernization.

Table 1. Descriptive Statistics of Elements' Relationship to Popular Culture

\begin{tabular}{ccc}
\hline Elements & $\begin{array}{c}\text { Strong Relationship } \\
\%\end{array}$ & $\begin{array}{c}\text { Weak Relationship } \\
\%\end{array}$ \\
\hline Critical theory & 55.5 & 24.5 \\
\hline Cinema & 79 & 16 \\
\hline Power & 45 & 41 \\
\hline Consumer culture & 77.5 & 14 \\
\hline Media & 88 & 10 \\
\hline Art & 45 & 31 \\
\hline Gender & 41 & 49 \\
\hline High/Low culture & 41 & 33 \\
\hline Image & 57 & 26.5 \\
\hline
\end{tabular}

\subsection{Elements and Popular Culture}

The participants observed a strong relationship between critical theory and popular culture because some participants noted that critical theory raised the problem and awareness of popular culture. Thus, $55.5 \%$ of the participants saw a strong link between the two. However, only almost $25 \%$ of the participants observed a weak relationship. Another element regarding modernization and popular culture was cinema that was related to popular culture at a high percentage. $79 \%$ of the participants stated that there was a very strong relationship between cinema and popular culture. Only $16 \%$ of them saw a weak link between the two. The third element was about power. The effect of power on popular culture was only $45 \%$, which meant that less than half of the participants perceived a strong relation between the two. Another element was consumer culture that composed $77.5 \%$ of the answers, which shows that the percentage was quite high. The strongest relationship was seen in the element of media that composed $88 \%$ of the participants. Art as another element formed $45 \%$ of the answers. The answers regarding gender and high/low culture were the same and constituted only $41 \%$ of the participants. Lastly, $57 \%$ of the participants saw a strong relationship between image and popular culture.

The strongest relationships were composed of the elements of media, cinema and consumer culture, while the weakest relationships were between power, gender and 
popular culture.

\subsection{Interview Findings}

In line with the findings obtained from the elements, the participants emphasized that media was the most important entity that produced popular culture because media imposes a lot of popular elements that motivate people to consume more about anything. Another entity related to media was image that is often created by media.

\subsection{Findings Regarding Media, Image and Consumer Culture}

The participants stressed the fact that media and image act together by tempting the individuals to consume popular entities. Some examples regarding popular culture are as follows:

We are always affected by media because media is always in our hands. We cannot escape media. It is always with use. (P1)

Media tries to evoke beautiful images so that we can be persuaded by them, and we are really persuaded. There seems no other way. (P2)

We are just consuming. We are constantly told to consume more. Wherever I go and whatever I do, I feel that I should consume more. I have no money but I just want to consume. I buy popular books and watch popular movies. (P3)

\subsection{Findings Regarding Cinema and Art}

The participants stated that cinema and popular can be related to popular culture. Most of them said that they spent their free time watching popular movies. However, art was considered an individual pursuit because art could not as popular as cinema. Some of them noted that cinema is an artistic piece but a popular artistic style because cinema attracts more people than art does. Art was perceived peculiar to high culture. Some examples regarding cinema and art are as follows:

To be honest, I have never seen a real artistic work or piece. However, I watch the best movies and series every day. Cinema is my biggest activity. I think it is popular. (P4)

Most of my friends including me spend our time watching movies and talk about them. As for art, we seem to have no interest in art. I do not know the reason. Maybe it is something cultural. (P5).

Cinema fills our void because I think it is easily accessible and reachable. Art is far away from us. I do not know where art is. If I saw an artistic piece, I believe I would understand nothing. (P6)

\subsection{Findings Regarding High/low culture, Power and Gender}

The participants expressed the facts that they were not interested in power or gender including high/low culture.
This was the first time that they encountered these concepts in this class. They stated that they had seen or read these terms before but had not reflected upon these concepts before. Therefore, these elements were less related to popular culture when compared to the other elements. The participants emphasized that modernization may have produced these terms. In addition, they stated that modernization may have created popular culture because traditional cultures did not have modernization or popular culture. Some examples regarding high/low culture, power and gender are as follows:

I do not think that gender is related to popular culture. Gender is a cultural issue. I have not thought about it much. It may be related to modernization but I am not sure. As for power, power is always there. I do not see any relationship regarding popular culture. (P7).

Power and gender are important but I believe that popular culture is about consumption, cinema and media. I have never been taught gender or power in the previous classes. Maybe popular culture is bad because it is related to low culture. Maybe high culture is related to modernization, gender and power but I am really not sure. (P8).

I know that I do not come from high culture which belongs to rich people, I think. Gender is tough. Power is about the government. Gender and power are not popular culture things. They are things I cannot interpret. (P9).

In this class, I learned that gender and power are strongly related to modernization and popular culture but I still do not know how. In my daily life, for me, popular culture is about movies, media and consuming things that I do not need. For example, I have iPhone. Actually, I do not need it. This is popular culture. (P10).

Based on the interviews, it can be interpreted that the participants developed or had some exemplars and prototypes regarding popular culture and modernization. These prototypes regarding popular culture were more related to media, image, cinema, consumer culture, whereas modernization was more related to art, high/low culture, gender and power. Media and cinema were interpreted as two most important entities of popular culture because most of the participants stated that media was in their hands and spend most of their time watching movies but could not develop an interest in art or other elements such as power and gender. Popular culture referred to concrete things and experiences for them such as having a phone and watching movies. Thus, power and gender issues were regarded as abstract because they have not had these experiences such as discussions in their classes. It can be said that modernization and popular culture were contrasted with each other in some respects, although they overlapped with each other in some ways.

\section{Discussion and Conclusions}

The aim of this study was to unearth the relationship 
between modernization-popular culture and 9 elements composed of critical theory, consumer culture, gender, cinema, media, high/low culture, power, art and image. Inglehart and Welzel [19] emphasize the fact that postindustrial modernization refers to individual autonomy and self-expression, whereas popular culture deconstructs these modern practices because the ruling class and media imposes elements of popular culture on people from low class [29]. This present study also showed that the participants linked the elements such as consumerism and cinema to the low class people, while art was related to high class individuals. In addition, popular culture was perceived as things that are concrete, tangible, functional and practical. However, the elements such as gender and power were partially seen as important parts of popular culture.

Some of the participants had difficulty operationalizing the elements of art, gender and power because it was stated that Turkish culture did not immerse them in these elements. Therefore, they could not develop any interest in these elements. This situation can be understood considering various perspectives developed in modernization theory that involves different changes in different societies $[19,21]$ because Turkey is seen as a collectivistic culture [20] that has adapted modernization in a different way.

Since some modernization practices such as art are related to high culture and individual pursuits [29], the participants in this present study also expressed that they were not consciously aware of these practices. However, they were constantly involved in media and cinema including consumerism. Bourdieu [6] also perceived popular culture as an important social element involving commercial purposes. In this sense, modernization can be seen as an alter ego of popular culture. That is, modernization has brought about individual elements such as autonomy and self-expression. However, it has also reinforced popular culture and culture industry $[2,29]$. Although Storey [29] articulates that popular culture is also associated with power, hegemony and ideology, the participants did not express that power and gender elements were related to popular culture. They think that modernization may have produced power, gender and high/low culture but the problem for them is that they were not involved in these practices owing to the possible effect of their culture. Adorno [2] notes that people are often manipulated by imposing techniques that direct people to consume more. In line with this finding, this study also showed that the participants were manipulated by the media to consume more since the element media was always easily accessible for them.

Kyong-Dong [21] assumes that modernization cannot be comprehended in a reductionist and western-based way because modernization and development are conceptualized and experienced in different ways in different societies. It can be said that the effect of culture industry emerging in the USA with cinema is deeply affected by the participants. In addition, one of the most effective determinants of popular culture, media, forms a prototype for the participants. In this sense, it can be said that there seems a strong relationship between some aspects of popular culture and the results obtained in this study. Modernization and popular culture accommodate certain contrasts with each other as well as some overlapping. However, popular culture appears to be perceived more dominant in the context of Turkey since it offers more concrete elements to individuals. However, popular culture elements such as gender, power, hegemony and ideology emphasized by Storey [29] are only partially addressed and articulated in the lives of individuals in Turkey.

\section{REFERENCES}

[1] Adorno, T. \& Horkheimer, M. (1979). Dialectic of Enlightenment, London: Verso.

[2] Adorno, T. W. (2001). The culture industry: Selected essays on mass culture. Psychology Press.

[3] Agger, B., \& Baldus, B. (1999). Critical social theories: An introduction. Canadian Journal of Sociology, 24(3), 426.

[4] Arat, Z. F. (1988). Democracy and economic development: Modernization theory revisited. Comparative Politics, 21(1), 21-36.

[5] Bennett, T. (1980). Popular culture: a teaching object. Screen Education, 34(18), 17-29.Bourdieu, P. (1984), Distinction: A Social Critique of the Judgment of Taste, translated by Richard Nice, Cambridge, Mass.: Harvard University Press

[6] Brannen, J. (Ed.). (2017). Mixing methods: Qualitative and quantitative research. London: Routledge.

[7] Bryman, A. (2004). Social Research Methods (2 ed.). Oxford: Oxford University Press.

[8] Creswell, J. W., \& Miller, D. L. (2000). Determining validity in qualitative inquiry Theory into Practice, 39(3), 124-131.

[9] Creswell, J. W., \& Poth, C. N. (2017). Qualitative inquiry and research design: Choosing among five approaches. Sage publications.

[10] Donovan, T., \& Bowler, S. (1998). Direct democracy and minority rights: an extension. American Journal of Political Science, 1020-1024.

[11] Featherstone, M. (1990). Global culture: an introduction. Theory, Culture \& Society, 7(2-3), 1-14.

[12] Findley, C. V. (1980). Bureaucratic Reform in the Ottoman Empire: The Sublime Porte, 1789-1922. Princeton University Press.

[13] Frey, B. S. (1994). Direct democracy: politico-economic lessons from Swiss experience. The American Economic Review, 84(2), 338-342. 
[14] Gramsci, A. (2009). Hegemony, intellectuals, and the state in Cultural Theory and Popular Culture: A Reader, 4th edn, edited by John Storey, Harlow: Pearson Education.

[15] Hall, S. (2009). The rediscovery of ideology: the return of the repressed in media studies in Cultural Theory and Popular Culture: A Reader, 4th edn, edited by John Storey, Harlow: Pearson Education.

[16] Huntington, S. P. (1991). The third Wave: Democratization in the late Twentieth Century. London: University of Oklahoma Press.

[17] Inglehart, R. (1997). Modernization and post modernization: Cultural, economic, and political change in 43 societies. Princeton University Press.

[18] Inglehart, R., \& Welzel, C. (2005). Modernization, cultural change, and democracy: The human development sequence. Cambridge: Cambridge University Press.

[19] Kim, U. E., Triandis, H. C., Kâğitçibaşi, Ç. E., Choi, S. C. E., \& Yoon, G. E. (1994). Individualism and collectivism: Theory, method, and applications. Sage Publications, Inc.

[20] Kyong-Dong, K. (2017). Alternative Discourses on Modernization and Development: East Asian Perspectives. Springer.

[21] Lipset, S. M. (1959). Some social requisites of democracy: Economic development and political legitimacy. American political science review, 53(1), 69-105.

[22] Lupia, A., \& Matsusaka, J. G. (2004). Direct democracy: new approaches to old questions. Annu. Rev. Polit. Sci., 7,
463-482.

[23] Maltby, R. (1989). Introduction in Dreams for Sale: Popular Culture in the 20th Century, edited by Richard Maltby, London: Harrap.

[24] Marcuse, H. (1968). One Dimensional Man. London: Sphere.

[25] Mardin, Ş. (2000). The genesis of young Ottoman thought: A study in the modernization of Turkish political ideas. Syracuse University Press.

[26] Pick, J. B., \& Butler, E. W. (2017). Socioeconomic inequality in the US-Mexico borderlands: Modernization and buffering. Frontera Norte, 2(3), 32-62.

[27] Przeworski, A. \& Fernando L. (1997). Modernization: Theories and Facts. World Politics, 49, pp. 155-83.

[28] Storey, J. (2015). Cultural theory and popular culture: An introduction. New York: Routledge.

[29] Tashakkori, A., \& Teddlie, C. (2003). Handbook of Mixed Methods in Social and Behavioral Research. Thousand Oaks, CA: Sage.

[30] Tipps, D. C. (1973). Modernization theory and the comparative study of national societies: A critical perspective. Comparative studies in society and history, 15(2), 199-226.

[31] Williams, R. (1963). Culture and Society, Harmondsworth: Penguin.

[32] Williams, R. (1983). Keywords. London: Fontana. 